\title{
Sodium butyrate in chicken nutrition: the dynamics of performance, gut microbiota, gut morphology, and immunity
}

U. AHSAN ${ }^{1}$, Ö. CENGIZ ${ }^{1 *}$, I. RAZA ${ }^{1}$, E. KUTER ${ }^{1}$, M.F.A. CHACHER ${ }^{2,3}$, Z. IQBAL ${ }^{4}$, S. $\mathrm{UMAR}^{5}$ and S. ÇAKIR ${ }^{6}$

${ }^{\mathbf{1}}$ Department of Animal Nutrition and Nutritional Diseases, Faculty of Veterinary Medicine, Adnan Menderes University, Aydın 09016, Turkey; ${ }^{2}$ University College of Veterinary and Animal Sciences, The Islamia University of Bahawalpur,

Bahawalpur 63100, Pakistan; ${ }^{3}$ Faculty of Veterinary Medicine, Ataturk University, Erzurum, Turkey; ${ }^{4}$ Department of Animal Sciences, School of Environmental and Rural Sciences, University of New England, Australia; ${ }^{5}$ National Veterinary School, Toulouse, France; ${ }^{6}$ Department of Poultry Science, Faculty of Agriculture, Abant Izzet Baysal University, Bolu, Turkey

*Corresponding author: ozcancen@gmail.com

The effect of sodium butyrate on various bodily parameters of broilers such as performance, gut microflora, gut morphology, and immunity is reviewed in order to highlight its importance as an alternative to antibiotic growth promoters. Sodium butyrate is used as a source of butyric acid, which is known for its beneficial effects in the gut in monogastrics. Sodium butyrate is available in uncoated and entericcoated forms protected with fat or fatty acid salts. Varying results in productive performance, gut microbes, and gut morphology have been reported in the literature in response to supplementation of broiler diets with uncoated and fatcoated types of sodium butyrate. However, sodium butyrate has shown pronounced effects on immunity of chickens that are not fully understood yet. Although there are contrasting results of sodium butyrate in chicken, further research is needed using the sodium butyrate coated with the salts of fatty acids.

Keywords: broiler; sodium butyrate; performance; gut microflora; immunity

\section{Introduction}

Antibiotics, since their discovery, have been used at therapeutic levels for the treatment of diseases, and at sub-therapeutic levels as growth promoters in animal feeds to improve production. Antibiotics had been considered as essential additives/supplements for better growth and maintaining gut ecosystem balance (Huyghebaert et al., 2011) for more than 50 years in poultry production. This supplementation was widely practiced for decades

(C) World's Poultry Science Association 2016

World's Poultry Science Journal, Vol. 72, June 2016

Received for publication September 29, 2015

Accepted for publication March 1, 2016 
until questioned due to increasing frequency of resistance to antibiotics in chicken (Kabir, 2009) along with dwindling efficacy in humans (Dibner and Richards, 2005). In the past 25 years, 38 new pathogens have emerged, of which $75 \%$ have originated from animals, a number of them due to inappropriate use of antibiotics. Almost 800 pathogens have crossed the species barrier from animals out of 1,400 pathogens causing human diseases. Hence, the awareness among the general public has increased concerns towards the antimicrobial resistance in pathogens. In 2006 the European Union imposed a complete ban on the use of antibiotics in poultry feeds (Singer and Hofacre, 2006; Vesna et al., 2007). As a consequence, the development of alternatives to antibiotics receives considerable attention. Ideally, alternatives to antibiotics should have the same advantageous properties. Isolated nutrients (amino acids, fatty acids, minerals, and vitamins), dietary supplements (probiotics, prebiotics, synbiotics, organic acids, antioxidants, and enzymes), herbal products (polyphenols, herbs, and spices) and genetically modified foods have been extensively studied in search of alternatives (Das et al., 2012). Among these alternatives, organic acids are considered to be popular and suitable for in-feed use. These compounds are defined as short chain fatty acids that beneficially affect the host by selectively stimulating the favourable growth or activity of beneficial bacterial species and killing the harmful bacteria populations inhabiting the digestive tract of poultry. These are natural products of the microbial metabolism or fermentation of the carbohydrates in the intestine of animals. The most commonly known organic acids are acetic acid, propionic acid, and butyric acid, also known as volatile fatty acids (VFAs) or short chain fatty acids (SCFAs). Among these, butyric acid possesses the interesting characteristic features. It has a molecular weight of $88.12 \mathrm{~g} / \mathrm{mol}$, density $0.958 \mathrm{~g} / \mathrm{ml}$, and $\mathrm{pKa} 4.82$. However, it is corrosive and volatile in nature, therefore the sodium salt of butyric acid is used which allows easy handling, stability and is less odorous.

Sodium butyrate is readily transformed into butyric acid within the digestive tract of the birds where it improves the intestinal health through various mechanisms. It is involved in the development of gut wall tissues and modulates the growth of symbiotic intestinal microflora (Van Immerseel et al., 2004; 2005; Friedman and BarShira, 2005; Leeson et al., 2005). It improves body weight, feed conversion ratio (FCR), beneficial bacterial populations, and reduces the colonisation of harmful bacteria in the digestive tract of broilers (Chamba et al., 2014; Zhang et al., 2011; Hu and Guo, 2007; Hernandez et al., 2013). In addition, sodium butyrate supplementation has been linked to improving immunity in broilers (Zhou et al., 2014). In this review, published data relating to the used and benefit of sodium butyrate in poultry diets is discussed.

\section{Structure of butyric acid and sodium butyrate}

Butyric acid belongs to the class of carboxylic acids consisting of a four carbon atoms chain, thus named as butanoic acid. The terminal carbon is a carbonyl carbon of the carboxyl group (-COOH), the functional group of the carboxylic acids, also known as 1butanoic acid. The hydrogen ion of hydroxyl group $(-\mathrm{OH})$ is weakly bonded and replaceable. In solution, butyric acid loses its hydrogen ion to form butyrate ion $\left(\mathrm{CH}_{3} \mathrm{CH}_{2} \mathrm{CH}_{2} \mathrm{COO}^{-}\right)$. Sodium butyrate is the sodium salt of butyric acid which contains sodium atom in place of hydrogen of $-\mathrm{OH}$ group. The structure of butyric acid and sodium butyrate has been shown in Figure 1. 


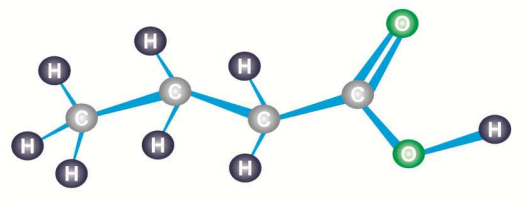

(a)

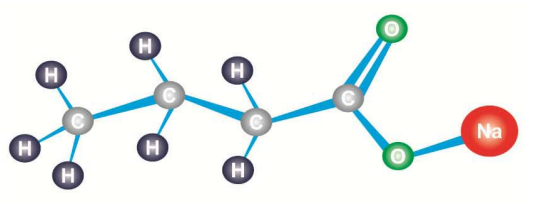

(b)

Figure 1 Structure of butyric acid and sodium butyrate (a) The carbonyl carbon atom in the carboxyl group (-COOH) is attached to one oxygen atom with double covalent bond, a hydroxyl group (-OH), and the carbon chain. Since the structure contains four carbon atoms including the carbonyl carbon, it is named as butanoic acid or commonly called butyric acid. (b) The hydrogen atom of the -OH group of butyric acid is replaced with sodium (Na). When butyric acid loses hydrogen ion $\left(\mathrm{H}^{+}\right)$of the $-\mathrm{OH}$ group, it is called butyrate ion $\left(\mathrm{CH}_{3} \mathrm{CH}_{2} \mathrm{CH}_{2} \mathrm{COO}^{-}\right)$. The attachment of sodium to butyrate ion makes its name sodium butyrate.

\section{Dissociation and absorption of butyric acid}

The efficacy of sodium butyrate depends upon the $\mathrm{pKa}$ value of butyric acid and $\mathrm{pH}$ of the corresponding part of the digestive system viz. crop, proventriculus, gizzard and small intestine. $\mathrm{pKa}$ is the $\mathrm{pH}$ value of an acid at which half the molecules of that acid are dissociated into positive and negative ions. At a $\mathrm{pH}$ of 4.82 , butyric acid remains in equilibrium between butyric acid, and butyrate and hydrogen ions. If the $\mathrm{pH}$ of a medium is less than the $\mathrm{pKa}$ value of butyric acid, most of the molecules of butyric acid remain un-dissociated. Therefore, it is important for butyric acid to stay un-dissociated to be efficient in that medium. This equilibrium is shown in the equation below, and the theoretical dissociation of butyric acid as a function of $\mathrm{pH}$ is shown in Figure 2.

$\mathrm{CH}_{3} \mathrm{CH}_{2} \mathrm{CH}_{2} \mathrm{COOH} \leftrightarrow \mathrm{CH}_{3} \mathrm{CH}_{2} \mathrm{CH}_{2} \mathrm{COO}^{-}+\mathrm{H}^{+}$

$$
\mathrm{pH}<4.82 \quad \mathrm{pH}=4.82 \quad \mathrm{pH}>4.82
$$

Sodium butyrate is converted into butyric acid after ingestion. The acidic $\mathrm{pH}$ of the crop, proventriculus, and gizzard allows butyric acid to stay in its un-dissociated form. As it enters the proximal small intestine, it is dissociated into butyrate and hydrogen ions (Figure 3). Butyric acid is readily absorbed by enterocytes via passive diffusion and used to increase villus length and cells turnover. However, most molecules of butyric acid are dissociated. Butyrate ions can be absorbed as a source of energy as well, which require different methods for their absorption. Butyrate ions can be transported either through diffusion, bicarbonate ion $\left(\mathrm{HCO}_{3}^{-}\right)$exchange method or by active transport (McNeil et al., 1979; Velazquez et al., 1997; Kawamata et al., 2007). Two different transporters have been proposed for the absorption of dissociated form of short chain fatty acids: the monocarboxylate transporter isoform 1 (MCT1) coupled with a transmembrane $\mathrm{H}^{+}$gradient, and SLC5A8 which is a $\mathrm{Na}^{+}$-coupled co-transport system also known as sodium coupled monocarboxylate transporter 1 (SMCT1) (Hamer et al., 2008). However, butyric acid is the preferred source of energy for the enterocytes (Mahdavi and Torki, 2009).

The bactericidal effects of butyric acid require it to be un-dissociated for entry into the bacterial cell. Therefore, it is necessary to use sodium butyrate in such a form that should protect it from dissociation, so enteric-coated forms of sodium butyrate have been developed in order to prevent its dissociation in proximal and distal portions of bird's 
intestine, and caking of the sodium butyrate. The different coatings include the palm stearin, vegetable fats, and salts of palm fatty acids. The palm stearin coating encapsulates only a low percentage of sodium butyrate, which requires a higher dosage in feed to reach a sufficient level of active ingredient in the animal (Puyalto and Mallo, 2014). Vegetable fat and fatty acid salts coating processes protect a higher level of sodium butyrate that is dissociated slowly along the length of gastrointestinal tract and which is much more effective to reduce the level of infectious bacteria.

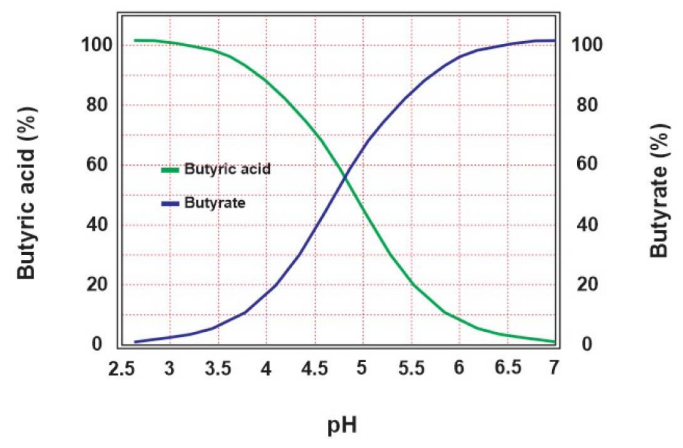

Figure 2 Effect of $\mathrm{pH}$ on dissociation of butyric acid. The acidic pH lower than the pKa (4.82) shifts the equilibrium towards the un-dissociated butyric acid on the left side of the graph whereas the increasing pH shifts the equilibrium towards the dissociated butyrate ions on the right side.

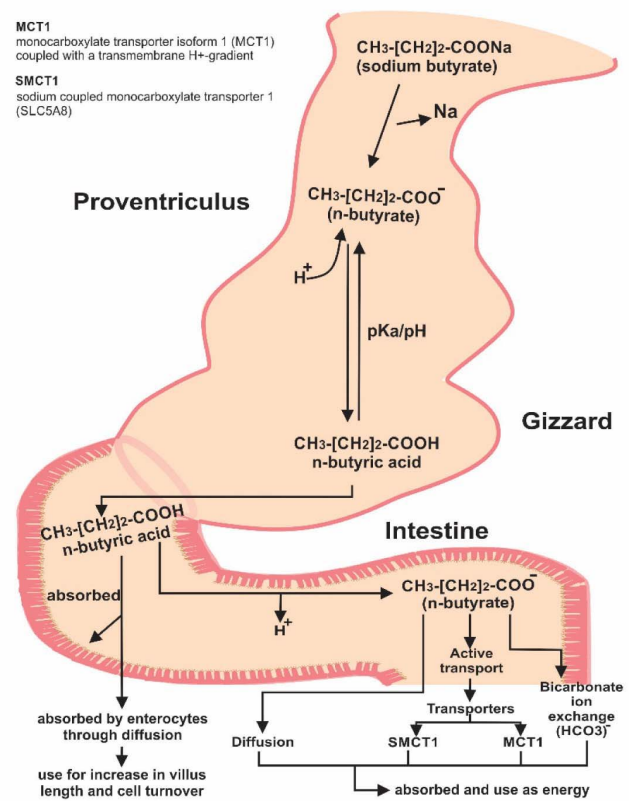

Figure 3 Conversion of sodium butyrate to butyric acid in the bird's intestine and its absorption. 


\section{Productive performance}

Beneficial health effects of butyrate or butyric acid are well documented, and it has been shown to have positive effects on broiler production parameters such as weight gain, feed intake, and FCR (Antongiovanni et al., 2007; Leeson et al., 2005; Taherpour et al., 2009). Chamba et al. (2014) reported that partially coated sodium butyrate in broiler diet significantly increased the feed intake and weight gain, and improved FCR as compared to positive and negative controls during grower and finisher phases but not in the starter phase. Mansoub (2011) reported that dietary sodium butyrate increased the weight gain and FCR up to 28 days of age. (Antongiovanni et al., 2007; Leeson et al., 2005; Taherpour et al., 2009). Similarly, butyric acid enhanced the weight gain and FCR (Panda et al., 2009). Likewise, partially protected and microencapsulated sodium butyrate positively affected the performance of broilers during the grower and finisher periods (Mallo et al., 2010; Zou et al., 2010a). Hernandez et al. (2013) found a significant increase in weight gain and FCR of broilers in commercial flocks in response to both uncoated and coated sodium butyrate. The improvement in the performance of broilers is considered due to different functions accomplished by sodium butyrate. Butyric acid increases the villi length in small intestine (Chamba et al., 2014; Adil et al., 2011) and stimulates the pancreatic exocrine (Katoh and Tsuda, $1984 ; 1985)$ thus increasing the secretions of digestive enzymes such as amylase and lipase. Consequently, the feed digestion and nutrient absorption is improved.

Contrary to these findings, Mahdavi and Torki (2009) reported that different levels of dietary sodium butyrate did not improve the weight gain and FCR of broilers. Similarly, dietary sodium butyrate did not increase the weight gain and FCR of the broilers (Leeson et al., 2005). Zhang et al. (2011) reported no significant difference in weight gain, feed intake and FCR of broilers fed different levels of sodium butyrate or without sodium butyrate. According to Zou et al. (2010a; 2010b), feed intake was not increased in response to dietary coated sodium butyrate or antibiotics. The variable findings in productive performance are due to the fact that uncoated sodium butyrate, when converted to butyric acid, is dissociated in the small intestine because of its low pKa value in comparison with the $\mathrm{pH}$ of small intestine. Thus, a considerable quantity of butyric acid (undissociated) from uncoated sodium butyrate cannot be used by enterocytes due to low concentrations that may not result in higher villi length. Consequently, nutrient absorption will be lower which leads to poor FCR and reduced weight gain. As the functionality of intestines of day old chicks and the activity of the digestive enzymes is not sufficiently developed (Ravindran, 2003), and fat coating is not emulsified completely (Noy and Sklan, 1994; Leeson and Summers, 2001), fat-coated sodium butyrate is not released completely. As a result, the digestion of feed and absorption of nutrients are not completely accomplished. This causes lowered weight gain and poor FCR during the starter period of chicken growth in response to fat-coated sodium butyrate and the carry-over effects may affect overall performance of birds.

\section{Gut microflora}

Sodium butyrate is a selective bactericidal agent due to its activity of lowering the $\mathrm{pH}$ of crop and gizzard and in the upper part of the intestine, controlling harmful bacteria such as Salmonella spp., Escherichia coli and Campylobacter jejuni (Van Deun et al., 2008). Chamba et al. (2014) did not report any effects of dietary sodium butyrate on E. coli populations in the jejunum in comparison with antibiotic supplemented diets. Similarly, the different concentrations of sodium butyrate in feed did not change E.coli populations 
in the jejunum (Hu and Guo, 2007). Likewise, a study showed that coated butyric acid proved to be the best bactericidal agent against Campylobacter jejuni in vitro in comparison with propionic acid, acetic acid and L-lactate (Van Deun et al., 2008). The same effect was observed in the presence of intestinal mucous with a higher dose of sodium butyrate in vitro, however, sodium butyrate supplementation in feed was not effective against $C$. jejuni (Van Deun et al., 2008). This implied that higher doses of sodium butyrate may be needed to be effective against $C$. jejuni. Another study revealed that sodium butyrate reduced the invasion of Salmonella enterica in intestinal epithelium of broilers (Van Immerseel et al., 2004) due to the downregulation of pathogenicity island 1 of S. enterica (SPI1; Gantois et al., 2006).

\section{Direct bactericidal effect of sodium butyrate}

After sodium butyrate is converted to butyric acid, it has the ability to enter the bacterial cell wall mainly through diffusion (Clark and Cronan, 1996) which causes toxicity inside the bacterial cell (Warnecke and Gill, 2005). The reduction in the cytoplasmic $\mathrm{pH}$ of the bacterial cell which in turn affects the purine bases (Choi et al., 2000) resulting in denaturing essential enzymes inside the cell (Roe et al., 2002), ultimately leading to the death of bacteria. Gantois et al. (2006) reported that when Salmonella spp. is grown in the presence of butyric acid, it downregulates the genes located in the SPI1 that results in reduced invasiveness of Salmonella spp. through intestinal epithelial cells. The bactericidal effect of butyric acid has been shown in Figure 4.

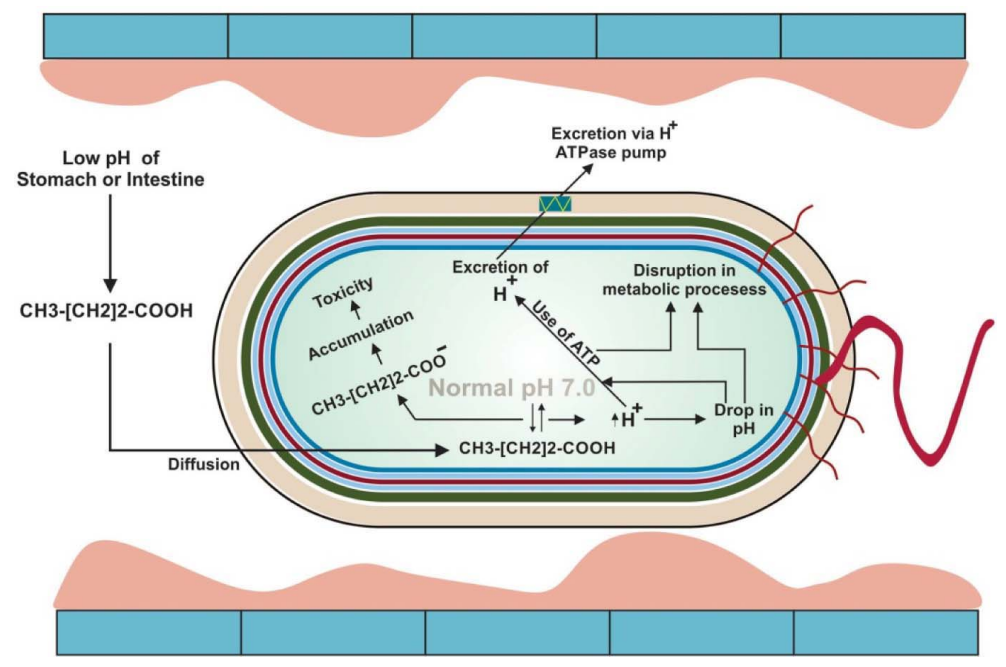

Figure 4 The bactericidal action of butyric acid. At low pH, the un-dissociated sodium butyrate enters into the bacterial cytoplasm. The $\mathrm{pH}$ of cytoplasm is neutral which dissociates the butyric acid into $\mathrm{H}^{+}$ and butyrate ions. Increase in $\mathrm{H}^{+}$ions decreases the $\mathrm{pH}$ of the cytoplasm which disrupts the metabolic process. The bacterial cell, at the expense of ATP, excretes the $\mathrm{H}^{+}$ions from its cytoplasm via $\mathrm{H}^{+}$ATPase pump. On the other hand, butyrate ions are accumulated, which causes toxicity in the cytoplasm. The bacterial cell is eventually exhausted and killed. 


\section{Indirect bactericidal effect of sodium butyrate}

Sodium butyrate lowers the $\mathrm{pH}$ of intestine that favours the growth of lactic acid producing bacteria such as Lactobacilli and Bifidobacteria spp. (Vogt et al., 1982) as they require an acidic medium for their growth. It has been reported that lactic acid producing bacteria compete for space and nutrients with pathogenic bacteria within the intestine (Furuse and Okumura, 1994; Rolfe, 2000). Lactobacilli spp. produce bacteriocins (Joerger, 2003) whereas Bifidobacteria spp. secrete some organic acids (acetic acid and lactic acid) and bactericidal substances (Gibson and Wang, 1994) which moderate the pathogenic bacterial count and maintain a healthy environment in the bird's intestine. Similarly, Audisio et al. (2000) reported that sodium butyrate favours the growth of Lactobacilli spp. that converts glucose to lactic acid within the intestine of birds, causing the inhibition of pathogenic bacteria such as Salmonella spp. and E.coli.

\section{Gut morphology}

Characteristic features of a bird's digestive tract for the optimal functions include large surface area covered with long healthy villi having shallow crypts (Ferket et al., 2002). Deeper crypts are indicative of rapid tissue turnover in order to permit renewal of villi and normal sloughing or pathogenic invasion resulting in inflammation (Miles et al., 2006). Long villi and shallow crypts provide a larger surface area for the absorption of nutrients and low renewal rate, allowing efficient enzyme production and maturation of the intestinal cells (Yang et al., 2009). Any alteration in the diet and the intestinal microflora can alter the morphology of gastrointestinal tract of broilers. Response of the bird's intestine to dietary changes may result in either shortening or lengthening of each villus which further affects the digestion and absorption of nutrients (Yang et al., 2007). As sodium butyrate is converted to butyric acid after ingestion, it is preferably absorbed by enterocytes as a source of energy (Mahdavi and Torki, 2009). It accelerates the growth of enterocytes and villus elongation that results in increased villi height and deeper crypts. It has been reported that villus height increased in the jejunum and ileum in response to dietary sodium butyrate (fat coated) whereas crypt depth and villus height to crypt depth ratio were not affected (Chamba et al., 2014). Significantly higher duodenal villi density was reported in response to $3 \%$ sodium butyrate in comparison with $2 \%$ sodium butyrate (Adil et al., 2011). Adil et al. (2010) reported that dietary butyric acid (3\% application rate) significantly increased the villus height in the duodenum and jejunum only. Similarly, many researchers have described the beneficial effect of dietary sodium butyrate on villi height and crypt depth in broilers at different phases of their growth (Antongiovanni et al., 2007; Mallo et al., 2012; Panda et al., 2009; Sayrafi et al., 2011; Smulikowska et al., 2009). On the contrary, some researchers did not find any effect of dietary sodium butyrate on villi height and crypt depth (Leeson et al., 2005).

The variation in results may be due to the fact that uncoated sodium butyrate, with a $\mathrm{pKa}$ value being lower than the $\mathrm{pH}$ of intestine, is dissociated into ions which cannot be readily absorbed by the enterocytes. Therefore, activity relating to improved intestinal function is limited only to the upper part of the intestine. However, the fat-coated sodium butyrate may overcome this problem as it is available to the lower parts of the small intestine. In addition, the release of sodium butyrate from the fat covering needs it to be degraded by the activity of lipase enzyme. The inability of the younger chick's pancreas to produce sufficient quantity of lipase enzyme (Ravindran, 2003) may result in 
decreased release of sodium butyrate leading to the lowered villi height and crypt depth in starter phase.

\section{Immunity}

Not much data is available describing the effect of sodium butyrate on the immune functions of broilers. Host defence peptides (HDPs), also known as antimicrobial peptides, exist in almost all forms of life and are an integral part of innate immunity (Brogden et al., 2003; Ganz, 2003). Chicken genome encodes for $14 \beta$-defensins (AvBD1-14) and four cathelicidins (fowlicidins 1-3 and cathelicidin-B1) as a member of HDPs system (Goitsuka et al., 2007; Lynn et al., 2007; Sunkara et al., 2011). HDPs exhibit their properties as broad spectrum antimicrobials against bacteria, enveloped viruses, fungi, and protozoa by direct binding and lysis of microbial membranes (Ganz, 2003), which prevents the development of resistance to HDPs in pathogens. Sunkara et al. (2011) reported that sodium butyrate induced HDP gene expression in chicken macrophage cells, monocytes, bone marrow cells, and jejunal and caecal explants. In addition, sodium butyrate enhanced the antibacterial activity of chicken monocytes and reduced the colonisation of Salmonella spp. in $S$. enteritidis challenged chickens. Similar findings were reported in response to oral supplementation of sodium butyrate or butyric acid that reduced the colonisation and shedding of $S$. enteritidis in broilers (Van Immerseel et al., 2005; Fernandez-Rubio et al., 2009). These findings may have arisen either due to the direct antibacterial activity of butyric acid (Van Immerseel et al., 2003) or due to the decreased invasiveness of Salmonella spp. (possibly due to the downregulation of genes in SPI1) through intestinal epithelium (Van Immerseel et al., 2003; Gantois et al., 2006). Sodium butyrate can inhibit the nitric oxide production and expression of cytokines such as IL-1 $\beta$, IL-6, IFN- $\gamma$, and IL-10 in chicken macrophage cells stimulated by the presence of S. typhimurium lipopolysaccharides (Zhou et al., 2014).

\section{Conclusions}

The effects of dietary sodium butyrate supplementation on productive performance, gut microflora, and gut morphology are well understood, although its effects on immunity of the chicken are not completely clear. However, varying results of uncoated and fat coated sodium butyrate supplementation in broilers have been reported. There is a room for further research on the use of sodium butyrate, particularly in the fatty acid-coated form and appropriate dose rates. Further studies are suggested to investigate the effects of sodium butyrate on immunity of the chicken.

\section{Acknowledgements}

The authors gratefully acknowledge the fellowship to Umair Ahsan from The Scientific and Technological Research Council of Turkey (TÜBİTAK) under the BIDDEB-2215 programme. 


\section{References}

ADIL, S., BANDAY, T., BHAT, G.A., MIR, M.S. and REHMAN M. (2010) Effect of dietary supplementation of organic acids on performance, intestinal histomorphology, and serum biochemistry of broiler chicken. Veterinary Medicine International doi: 10.4061/2010/479485.

ADIL, S., BANDAY, T., BHAT, G.A., SALAHUDDIN, M., RAQUIB, M. and SHANAZ, S. (2011) Response of broiler chicken to dietary supplementation of organic acids. Journal of Central European Agriculture 12: 498-508.

ANTONGIOVANNi, M., BUCCIONI, A., PETACCHI, F., LEESON, S., MINIERI, S., MARTINI, A. and CECCHI, R. (2007) Butyric acid glycerides in the diet of broiler chickens: effects on gut histology and carcass composition. Italian Journal of Animal Science 6: 19-25.

AUDISIO, M.C., OLIVER, G. and APELLA, M.C. (2000) Protective effect of Enterococcus faecium J96, a potential probiotic strain, on chicks infected with Salmonella pullorum. Journal of Food Protection 63: 13331337.

BROGDEN, K.A., ACKERMANN, M., MCCRAY, P.B. Jr and TACK, B.F. (2003) Antimicrobial peptides in animals and their role in host defences. International Journal of Antimicrobial Agents 22: 465-478.

CHAMBA, F., PUYAlTO, M., ORTIZ, A., TORREALBA, H., MALlO, J.J. and RIBOTY, R. (2014) Effect of partially protected sodium butyrate on performance, digestive organs, intestinal villi and E.coli development in broilers chickens. International Journal of Poultry Science 13: 390-396.

CHOI, S.H., BAUMLER, D.J. and KASPAR, C.W. (2000) Contribution of dps to acid stress tolerance and oxidative stress tolerance in Escherichia coli O157 : H7. Applied and Environmental Microbiology 66: 39113916.

CLARK, D.P. and CRONAN, J.E. Jr (1996) Two-carbon compounds and fatty acids as carbon sources, in: NEIDHARDT, F.C., CURTISS III, R., INGRAHAM, J.L., LIN, E.C.C., LOW, K.B., MAGASANIK, B., REZNIKOFF, W.S., RILEY, M., SCHAECHTER, M. \& UMBARGER, H.E. (Eds) Escherichia coli and Salmonella: Cellular and Molecular Biology, 2nd ed., vol. 1, pp. 343-357 (Washington DC, USA, American Society for Microbiology).

DAS, L., BHAUMIK, E., RAYCHAUDHURI, U. and CHAKRABORTY, R. (2012) Role of nutraceuticals in human health. Journal of Food Science Technology 49: 173-183.

DIBNER, J.J. and RICHARDS, J.D. (2005) Antibiotic growth promoters in agriculture: History and mode of action. Poultry Science 84: 634-643.

FERKET, P.R., PARKS, C.W. and GRIMES, J.L. (2002) Benefits of dietary antibiotic and mannan oligosaccharide supplementation for poultry. Proceedings of the Multi-State Poultry Meeting. Indianapolis, Indiana.

FERNANDEZ-RUBIO, C., ORDONEZ，C., ABAD-GONZALEZ，J., GARCIA-GALLEGO, A., HONRUBIA, M.P., MALLO, J.J. and BALANA-FOUCE, R. (2009) Butyric acid-based feed additives help protect broiler chickens from Salmonella enteritidis infection. Poultry Science 88: 943-948.

FRIEDMAN, A. and BAR-SHIRA, E. (2005) Effect of nutrition on development of immune competence in chickens gut associated lymphoid system. Proceedings of 15th European Symposium on Poultry Nutrition, Balatonfüred, Hungary, pp. 234-242.

FURUSE, M. and OKUMURA, J. (1994) Nutritional and physiological characteristics in germ-free chickens. Comparative Biochemistry and Physiology Part A: Physiology 109: 547-556.

GANTOIS, I., DUCATElle, R., PASMANS, F., HAESEBROUCK, F., HAUTEFORT, I., THOMPSON, A., HINTON, J.C. and VAN IMMERSEEL, F. (2006) Butyrate specifically down-regulates Salmonella pathogenicity island 1 gene expression. Applied and Environmental Microbiology 72: 946-949.

GANZ, T. (2003) Defensins: antimicrobial peptides of innate immunity. Nature Reviews Immunology 3: 710 720.

GIBSON, G.R. and WANG, X. (1994) Regulatory effects of bifidobacteria on the growth of other colonic bacteria. The Journal of Applied Bacteriology 77: 412-420.

GOITSUKA, R., CHEN, C.L., BENYON, L., ASANO, Y., KITAMURA, D. and COOPER, M.D. (2007) Chicken cathelicidin-B1, an antimicrobial guardian at the mucosal M cell gateway. Proceeding of the National Academy of Sciences 104: 15063-15068.

HAMER, H.M., JONKERS, D., VENEMA, K., VANHOUTVIN, S., TROOST, F.J. and BRUMMER, R.J. (2008) Review article: the role of butyrate on colonic function. Alimentary Pharmacology and Therapeutics 27: 104-119.

HeRnANDEZ, J., AFANAdor, G., ARIZA-NIETO, C. and AVElLANEDA, Y. (2013) Evaluation of coated and powder sodium butyrate in diets for broilers reared with reused litter during a commercial production cycle. Journal of Animal Science 91(E-Suppl. 2): 335.

HU, Z. and GUO, Y. (2007) Effects of dietary sodium butyrate supplementation on the intestinal morphological structure, absorptive function and gut flora in chickens. Animal Feed Science and Technology 132: 240-249.

HUYGHEBAERT, G., DUCATELLE, R. and VAN IMMERSEEL, F. (2011) An update on alternatives to antimicrobial growth promoters for broilers. The Veterinary Journal 187: 182-188. 
JOERGER, R.D. (2003) Alternatives to antibiotics: bacteriocins, antimicrobial peptides and bacteriophages. Poultry Science 82: 640-647.

KABIR, S.M.L. (2009) The role of probiotics in the poultry industry. International Journal of Molecular Sciences 10: 3531-3546.

KATOH, K. and TSUDA, T. (1984) Effects of acetylcholine and short-chain fatty acids on acinar ceils of the exocrine pancreas in sheep. The Journal of Physiology 356: 479-489.

KATOH, K. and TSUDA, T. (1985) Effects of secretagogues on membrane potential and input resistance of pancreatic acinar cells of sheep. Research in Veterinary Science 38: 250-251.

KAWAMATA, K., HAYASHI, H. and SUZUKI, Y. (2007) Propionate absorption associated with bicarbonate secretion in vitro in the mouse cecum. Pflügers Archiv 454: 253-262.

LEESON, S., NAMKUNG, H., ANTONGIOVANNI, M. and LEE, E.H. (2005) Effect of butyric acid on the performance and carcass yield of broiler chickens. Poultry Science 84: 1418-1422.

LEESON, S. and SUMMERS, J.D. (2001) Nutrition of the chicken 4th Ed. Guelph, Ontario, Canada: University Books.

LYNN, D.J., HIGGS, R., LLOYD, A.T., O'FARRELLY, C., HERVE-GREPINET, V., NYS, Y. and BRINKMAN, F.S.L. (2007) Avian beta-defensin nomenclature: a community proposed update. Immunology Letters 110: 86-89.

MAHDAVI, R. and TORKI, M. (2009) Study on usage period of dietary protected butyric acid on performance, carcass characteristics, serum metabolite levels and humoral immune response of broiler chickens. Journal of Animal Veterinary Advances 8: 1702-1709.

MALlO, J.J., GRACIA, M., HONRUBIA, P. and PUYALTO, M. (2010) Effect of butyrate on broiler performance. Proceedings of XIIIth European Poultry Conference, Tours, France.

MALLO, J.J., PUYALTO, M. and RAMA RAO, S.V. (2012) Evaluation of the effect of sodium butyrate addition to broiler diet on energy and protein digestibility productive parameters and size of intestinal villi of animals. Feed and Livestock 8: 26-30.

MANSOUB, N.H. (2011) Comparative effect of butyric acid, probiotic and garlic on performance and serum composition of broilers chickens. American Eurasian Journal of Agricultural and Environmental Sciences 11: $507-511$.

McNEIL, N.I., CUMMINGS, J.H. and JAMES, W.P. (1979) Rectal absorption of short chain fatty acids in the absence of chloride. Gut 20: 400-403.

MILES, R.D., BUTCHER, G.D., HENRY, P.R. and LITTELL, R.C. (2006) Effect of antibiotic growth promoters on broiler performance, intestinal growth parameters, and quantitative morphology. Poultry Science 85: 476-485.

NOY, Y. and SKLAN, D. (1994) Enzyme secretion and small intestinal passage time in the young chick. Proceedings 9th European Poultry Conference, Glasgow, UK. pp. 451-452.

PANDA, A.K., RAO, S.V.R., RAJU, M.V.L.N. and SUNDER, C.S. (2009) Effect of butyric acid on performance, gastrointestinal tract health and carcass characteristics in broiler chickens. AsianAustralasian Journal of Animal Sciences 22: 1026-1031.

PUYALTO, M. and MALLO, J.J. (2014) Sodium butyrate - a new step in proper protection. Technical Bulletin No. 29, Norel SA, Spain.

RAVINDRAN, V. (2003) Development of digestive function in neonatal poultry: physiological limitations and potential. Proceedings of the 15th Annual Australian Poultry Science Symposium, Sydney, Australia, pp. 1-7.

ROE, A.J., O'BYRNE, C., MCLAGGAN, D. and BOOTH, I.R. (2002) Inhibition of Escherichia coli growth by acetic acid: a problem with methionine biosynthesis and homocysteine toxicity. Microbiology 148: 2215 2222

ROLFE, R.D. (2000) The role of probiotic cultures in the control of gastrointestinal health. The Journal of Nutrition 130: 396S-402S.

SAYRAFI, R., SOLTANALINEJAD, F., SHAHROOZ, R. and RAHIMI, S. (2011) Effects of butyric acid glycerides and antibiotic growth promoter on the performance and intestinal histomorphometry of broiler chickens. Journal of Food, Agriculture and Environment 9: 285-288.

SINGER, R.S. and HOFACRE, C.L. (2006) Potential impacts of antibiotic use in poultry production. Avian Diseases 50: 161-172.

SMULIKOWSKA, S., CZERWINSKI, J., MIECZKOWSKA, A. and JANKOWIAK, J. (2009) The effect of fat-coated organic acid salts and a feed enzyme on growth performance, nutrient utilisation, microflora activity, and morphology of the small intestine in broiler chickens. Journal of Animal and Feed Sciences 18: 478-489.

SUNKARA, L.T., ACHANTA, M., SCHREIBER, N.B., BOMMINENI, Y.R., DAI, G., JIANG, W., LAMONT, S., LILLEHOJ, H.S., BEKER, A., TEETER, R.G. and ZHANG, G. (2011) Butyrate enhances disease resistance of chickens by inducing antimicrobial host defense peptide gene expression. PLoS One 6: e27225. doi:10.1371/journal.pone.0027225. 
TAHERPOUR, K., MORAVEJ, H., SHIVAZAD, M., ADIBMORADI, M. and YAKHCHALI, B. (2009) Effects of dietary probiotic, prebiotic and butyric acid glycerides on performance and serum composition in broiler chickens. African Journal of Biotechnology 8: 2329-2334.

VAN DEUN, K., HAESEBROUCK, F., VAN IMMERSEEL, F., DUCATELLE, R. and PASMANS, F. (2008) Short chain fatty acids and L-lactate as feed additives to control Campylobacter jejuni infections in broilers. Avian Pathology 37: 379-383.

VAN IMMERSEEL, F., BOYEN, F., GANTOIS, I., TIMBERMONT, L., BOHEZ, L., PASMANS, F., HAESEBROUCK, F. and DUCATELLE, R. (2005) Supplementation of coated butyric acid in the feed reduces colonisation and sheeding of Salmonella in poultry. Poultry Science 84: 1851-1856.

VAN IMMERSEel, F., DE BUCK, J., PASMANS, F., VELGE, P., BOTTREAU, E., FIEVEZ, V., HAESEBROUCK, F. and DUCATELLE, R. (2003) Invasion of Salmonella enteritidis in avian intestinal epithelial cells in vitro is influenced by short-chain fatty acids. International Journal of Food Microbiology 85: 237-248.

VAN IMMERSEel, F., FIEVEZ, V., DE BUCK, J., PASMANS, F., MARTEL, A., HAESEBROUCK, F. and DUCATELLE, R. (2004) Microencapsulated short-chain fatty acids in feed modify colonisation and invasion early after infection with Salmonella enteritidis in young chickens. Poultry Science 83: 69-74.

VELAZQUEZ, O.C., LEDERER, H.M. and ROMBEAU, J.L. (1997) Butyrate and the colonocyte. Production, absorption, metabolism, and therapeutic implications. Advances in Experimental Medicine and Biology 427: 123-134.

VESNA, T., LAZAREVIĆ, M., SINOVEC, Z. and TOKIĆ, A. (2007) The influence of different feed additives to performances and immune response in broiler chicken. Acta Veterinaria 57: 217-229.

VOGT, H., MATTHES, S. and HARNISCH, S. (1982) The effect of organic acids on productivity of broilers. Archives für Geflügelkunde 46: 223-227.

WARNECKE, T. and GILL, R.T. (2005) Organic acid toxicity, tolerance, and production in Escherichia coli biorefining applications. Microbial Cell Factories 4: 25.

YANG, Y., IJI, P.A. and CHOCT, M. (2009) Dietary modulation of gut microflora in broiler chickens: a review of the role of six kinds of alternatives to in-feed antibiotics. World's Poultry Science Journal 65: 97114.

YANG, Y., IJI, P.A., KOCHER, A., MIKKELSEN, L.L. and CHOCT, M. (2007) Effects of mannanoligosaccharide on growth performance, the development of gut microflora and gut function of broiler chickens raised on new litter. The Journal of Applied Poultry Research 16: 280-288.

ZHANG, W.H., JIANG, Y., ZHU, Q.F., GAO, F., DAI, S.F., CHEN, J. and ZHOU, G.H. (2011) Sodium butyrate maintains growth performance by regulating the immune response in broiler chickens. British Poultry Science 52: 292-301.

ZHOU, Z.Y., PACKIALAKSHMI, B., MAKKAR, S.K., DRIDI, S. and RATH, N.C. (2014) Effect of butyrate on immune response of a chicken macrophage cell line. Veterinary Immunology and Immunopathology 162: 24-32.

ZOU, Y., YANG, Z.B., YANG, W.R., JIANG, S.Z., ZHANG, G.G. and YU, R. (2010a) Effects of coated sodium butyrate on the performance and gut morphology of broiler chickens. Poultry Science 89(E-Suppl 1): 385.

ZOU, Y., YANG, Z.B., YANG, W.R., JIANG, S.Z., ZHANG, G.G. and YU, R. (2010b) Effects of Sodium Butyrate on gut $\mathrm{pH}$ value, gut VFA and cecal microflora of broilers. Technical article on line of Hangzhou King Techina Technology Co Ltd. 